\title{
Prediction of pulmonary complications after a lobectomy in patients with non-small cell lung
}

\section{cancer}

H Uramoto, R Nakanishi, Y Fujino, H Imoto, M Takenoyama, T Yoshimatsu, T Oyama, T Osaki, K Yasumoto

\begin{abstract}
Background-Although the preoperative prediction of pulmonary complications after lung major surgery has been reported in various papers, it still remains unclear.

Methods-Eighty nine patients with stage I-IIIA non-small cell lung cancer (NSCLC) who underwent a complete resection at our institute from 1994-8 were evaluated for the feasibility of making a preoperative prediction of pulmonary complications. All had either a predicted postoperative forced vital capacity (FVC) of $>800 \mathrm{ml} / \mathrm{m}^{2}$ or forced expiratory volume in one second $\left(\mathrm{FEV}_{1}\right)$ of $>600 \mathrm{ml} / \mathrm{m}^{2}$.

Results-Postoperative complications occurred in 37 patients $(41.2 \%)$ but no patients died during the 30 day period after the operation. Pulmonary complications occurred in 20 patients $(22.5 \%)$. Univariate analysis indicated that the factors significantly related to pulmonary complications were FVC $<80 \%$, serum lactate dehydrogenase (LDH) level $\geqslant 230 \mathrm{U} / 1$, and arterial oxygen tension $\left(\mathrm{PaO}_{2}\right)<10.6 \mathrm{kPa}$ $(80 \mathrm{~mm} \mathrm{Hg})$. In a multivariate analysis the three independent predictors of pulmonary complications were serum LDH $\geqslant 230 \mathrm{U} / 1$ (odds ratio (OR) $10.5,95 \%$ CI 1.4 to 77.3$)$, residual volume (RV)/total lung capacity (TLC) $\geqslant 30 \%$ (OR 6.0, 95\% CI 1.1 to 33.7), and $\mathrm{PaO}_{2}<10.6 \mathrm{kPa}(\mathrm{OR} 5.6,95 \%$ CI 1.4 to 22.2).

Conclusions-The above findings indicate that three factors (serum LDH levels of $\geqslant 230 \mathrm{U} / 1, \mathrm{RV} / \mathrm{TLC} \geqslant 30 \%$, and $\mathrm{PaO}_{2}$ $<10.6 \mathrm{kPa}$ ) may be associated with pulmonary complications in patients undergoing a lobectomy for NSCLC, even though the patient group was relatively small for statistical analysis of such a diverse subject as pulmonary complications.

(Thorax 2001;56:59-61)
\end{abstract}

Keywords: non-small cell lung cancer; pulmonary complications; morbidity

Lung cancer is the leading cause of death among cancer patients. ${ }^{1}$ The necessity for surgical treatment is increasing because complete surgical removal of a tumour offers the best chance for a cure in patients with non-small cell lung cancer (NSCLC). ${ }^{23}$ A lobectomy remains the standard therapeutic option in most patients with early stage NSCLC. Although the operative mortality and morbidity following a lobectomy has decreased over the past decade, both factors still contribute significantly to the cost of treating such patients. Careful selection of the operative modalities is therefore required to reduce the overall mortality and morbidity.

Clinicians are often faced with the problem of morbidity, especially pulmonary complications, which tend to be impossible to predict. Pulmonary complications after lung resection can have serious consequences because the remaining lung tissue is severely compromised during the immediate postoperative period. In the present study we have reviewed a series of patients with NSCLC to evaluate the feasibility of preoperatively predicting pulmonary complications.

\section{Methods}

PATIENTS

From April 1994 to December 1998, 299 patients with primary lung cancer underwent lung resection at the Department of Surgery II, University of Occupational and Environmental Health, Kitakyushu, Japan. Of these, 89 patients with stage I-IIIA NSCLC in whom lobectomy was performed were assessed. All patients underwent the following diagnostic procedures preoperatively: brain computed tomographic (CT) scan, body CT scan, a pulmonary perfusion scintigraphic scan, and a bone scintigraphic scan. Spirometric tests were performed according to established guidelines. ${ }^{4}$ We calculated the predicted residual pulmonary function combined with xenon ventilation/perfusion scans from the ratio of right versus left fractional perfusion. The formula for the predicted residual pulmonary function is as follows:

Predicted residual pulmonary function $=$ pulmonary function $\times(1-$ ratio of lung perfusion on the resected side $\times$ number of resected pulmonary segments/number of pulmonary segments on the resected side)

In our institution surgery is indicated in patients with a predicted postoperative forced vital capacity (FVC) of $>800 \mathrm{ml} / \mathrm{m}^{2}$ or a forced expiratory volume in one second $\left(\mathrm{FEV}_{1}\right)$ of $>600 \mathrm{ml} / \mathrm{m}^{2}$. Routine systematic lymphadenectomy of hilar and mediastinal lymph nodes was performed in all cases. The charts were then retrospectively reviewed. The ineligibility factors are shown in table 1 . The 19 variables listed in table 2 were evaluated.

POSTOPERATIVE COMPLICATIONS

The pulmonary complications included atelectasis and sputum retention requiring bron- 


\section{Table 1 Ineligible factor}

Personal characteristics

Karnofsky performance status: $70 \%$ or less

Diabetes mellitus, cardiac disease or others requiring medication

Preoperative chemotherapy and/or radiotherapy

Interstitial change detected by CT scan

Pulmonary function test

Both predicted postoperative FVC of $800 \mathrm{ml} / \mathrm{m}^{2}$ or less and predicted postoperative $\mathrm{FEV}_{1}$ of $600 \mathrm{ml} / \mathrm{m}^{2}$ or less

Tumour characteristics

Small cell carcinoma or low grade malignant tumour

Confirmed histological diagnosis of stage IIIB or IV

Surgical characteristics

Residual tumour at the surgical margin

Incomplete systematic lymphadenectomy such as sampling

Less than lobectomy such as wedge resection or partial resection

Extent resection such as bilobectomy or pneumonectomy

Mechanical stapling devices for bronchial stump closure

Combined resection

Previous thoracic surgery such as thoracoplasty

Blood transfusion at operation

$\mathrm{CT}=$ computed tomography; $\mathrm{FEV}_{1}=$ forced expiratory volume in one second $\mathrm{FVC}=$ forced vita capacity.

choscopy, pneumonia defined by radiographic infiltrates plus at least two of the following: temperature $>37.7^{\circ} \mathrm{C}$, white blood cell count $>10500 / \mathrm{mm}^{3}$, initiation of antibiotic therapy, an

Table 2 Variables (category) evaluated for morbidity

\begin{tabular}{|c|c|}
\hline $\begin{array}{l}\text { Preoperative general } \\
\text { Age } \\
\text { Sex } \\
\text { Brinkmann index } \\
\text { Serum total protei } \\
\text { Serum albumin } \\
\text { Serum LDH } \\
\% \mathrm{FVC} \\
\% \mathrm{FEV}_{1} \\
\mathrm{FEV}_{1}(\%) \\
\mathrm{RV}^{\prime} \mathrm{TLC} \\
\mathrm{PaO}_{2} \\
\mathrm{PacO}_{2} \\
\text { Surgical factors (thr } \\
\text { Operative procedu }_{\text {Operated site }} \\
\text { Oxistence of adhes }_{\text {. }} \\
\text { Oncological factors } \\
\text { Pathological T sta } \\
\text { Pathological N sta } \\
\text { Pathological stage } \\
\text { Histological type }\end{array}$ & lables) \\
\hline \multicolumn{2}{|c|}{$\begin{array}{l}\mathrm{LDH}=\text { lactate dehydrogenase } \mathrm{FVC}=\text { forced vital capacity; } \\
\mathrm{FEV}_{1}=\text { forced expiratory volume in one second; } \mathrm{RV}=\text { residual } \\
\text { volume; TLC = total lung capacity; } \mathrm{PaO}_{2}, \mathrm{PaCO}_{2}=\text { arterial oxy- } \\
\text { gen and carbon dioxide tensions. }\end{array}$} \\
\hline \multicolumn{2}{|c|}{$\begin{array}{l}\text { Table } 3 \text { Postoperative complications in patients } \\
\text { undergoing a lobectomy with NSCLC }\end{array}$} \\
\hline Complication type & No of patients (\%) \\
\hline $\begin{array}{l}\text { Any complication } \\
\text { Respiratory } \\
\text { Atelectasis } \\
\text { Air leak } \\
\text { Pneumonia } \\
\text { Sputum retention } \\
\text { Bronchial asthma } \\
\text { Chylothorax } \\
\text { Empyema }\end{array}$ & $\begin{array}{c}37(41.2) \\
20(22.5) \\
8(9.0) \\
7(7.9) \\
2(2.2) \\
2(2.2) \\
2(2.2) \\
1(1.1) \\
1(1.1)\end{array}$ \\
\hline
\end{tabular}

Some patients had more than one complication.

Table 4 Univariate analysis of the perioperative variables contributing to the occurrence of pulmonary complications following a lobectomy

\begin{tabular}{lllll}
\hline Variable & Category & $\begin{array}{l}\text { No of } \\
\text { patients }\end{array}$ & $\begin{array}{l}\text { No (\%) of patients with } \\
\text { pulmonary complications }\end{array}$ & p value \\
\hline Serum LDH (U/l) & $<230$ & 83 & $16(19.3 \%)$ & 0.007 \\
& $\geqslant 230$ & 6 & $4(66.7 \%)$ & 0.04 \\
FVC $(\%)$ & $<80$ & 5 & $3(60.0 \%)$ & 0.002 \\
$\mathrm{PaO}_{2}(\mathrm{kPa})$ & $\geqslant 80$ & 84 & $17(20.2 \%)$ & \\
& $\geqslant 10.6$ & 15 & $8(53.3 \%)$ & \\
& $\geqslant 10.6$ & 74 & $12(16.2 \%)$ &
\end{tabular}

$\mathrm{LDH}=$ lactate dehydrogenase $\mathrm{FVC}=$ forced vital capacity; $\mathrm{PaO}_{2}=$ arterial oxygen tension. air leak requiring a thoracostomy tube drainage for more than seven days, bronchial asthma, chylothorax, and empyema. Cardiac complications included atrial fibrillation, bradycardia, and premature ventricular contractions, all of which required treatment. Other complications included liver dysfunction, gastric ulcer defined by endoscopy, depression, wound infection, and colitis, which all required treatment.

\section{STATISTICAL ANALYSIS}

The $\chi^{2}$ test was used to examine the association between the incidence of complications and clinicopathological features. When the expected value was $<5$ the Fisher's exact test was used. Variables with a $\mathrm{p}$ value of $<0.3$ were entered into the multivariate logistic regression program of the SAS. ${ }^{5}$ The cut off values were chosen to reflect extreme values over the normal range, or the clinical usefulness of these parameters. A p value of $<0.05$ was considered significant.

\section{Results}

STUDY POPULATION

The mean (SD) age of the patients was 67.2 (8.6) years (range 42-85). There were 62 men and 27 women. Twenty four patients had squamous cell carcinoma, 60 had adenocarcinoma, three had large cell carcinoma, one had adenosquamous cell carcinoma, and one had large cell neuroendocrine carcinoma. According to the new international staging system for lung cancer ${ }^{6}$ following a complete systematic lymphadenectomy carried out in all patients, the staging was as follows: 43 patients were stage IA, 26 were stage IB, two were stage IIA, six patients were stage IIB, and 12 patients were stage IIIA. Pulmonary function tests showed a restrictive defect in five $(5.6 \%)$, an obstructive defect in eight $(9.0 \%)$, and a combined defect in three $(3.4 \%)$.

\section{COMPLICATIONS}

All patients were extubated on the day of the operation. There were no deaths (operative mortality rate $0 \%$ ) and re-operation was required in only one patient $(1.1 \%)$ following empyema. No patient needed either mechanical ventilation or a tracheostomy. Overall, postoperative complications occurred in 37 patients (41.2\%). Pulmonary complications occurred in 20 patients $(22.5 \%)$. The postoperative complications and their incidence are shown in table 3.

PREDICTORS OF POSTOPERATIVE COMPLICATIONS The univariate predictions of pulmonary complications including age, sex, history of smoking, serum total protein, serum albumin, $\% \mathrm{FEV}_{1}$, $\mathrm{FEV}_{1} \%$, RV/TLC, hypercapnia, operative procedure, operated site, the existence of adhesions at operation, the pathological $\mathrm{T}$ and $\mathrm{N}$ stage, and the histological type were not predictive of pulmonary complications. FVC of $<80 \%$, serum $\mathrm{LDH}$ levels of $\geqslant 230 \mathrm{U} / \mathrm{l}$, and arterial oxygen tension $\left(\mathrm{PaO}_{2}\right)$ of $<10.6 \mathrm{kPa}(80 \mathrm{~mm} \mathrm{Hg})$ were predictive of complications (table 4). In a multivariate analysis these three factors were found to be significant independent predictors of pulmonary complications (table 5). 
Table 5 Multivariate analysis of the perioperative variables contributing to the occurrence of pulmonary complications following a lobectomy

\begin{tabular}{lllll}
\hline Variable & Category & Odds ratio & 95\% confidence interval & p value \\
\hline Serum LDH (U/1) & $\geqslant 230$ & 10.530 & 1.434 to 77.331 & 0.0207 \\
RV/TLC (\%) & $\geqslant 230$ & 1 & & \\
& $\geqslant 30$ & 6.015 & 1.074 to 33.688 & 0.0412 \\
$\mathrm{PaO}_{2}(\mathrm{kPa})$ & $<30$ & 1 & & 0.0145 \\
& $\geqslant 10.6$ & 5.584 & 1.407 to 22.168 &
\end{tabular}

$\overline{\mathrm{LDH}}=$ lactate dehydrogenase $\mathrm{RV}=$ residual volume; $\mathrm{TLC}=$ total lung capacity; $\mathrm{PaO}_{2}=$ arterial oxygen tension.

\section{Discussion}

Advances in operative techniques and postoperative care have led to a further decline in the postoperative complication rates following a lobectomy with a mortality rate of 1-9\% reported in recent studies ${ }^{7-9}$ and morbidity occurring at an alarming rate of $11-47 \% .^{8-10}$ These mortality and morbidity data are generally obtained from eligible patients who are selected on the basis of their pulmonary function and other organ functions. We also selected surgical candidates on the basis of either a predicted postoperative $\mathrm{FVC}$ of $>800 \mathrm{ml} / \mathrm{m}^{2}$ or an $\mathrm{FEV}_{1}$ of $>600 \mathrm{ml} / \mathrm{m}^{2}$. The resulting $0 \%$ mortality suggests that our criteria appear to be generally acceptable. However, some morbidity still remains even in these selected patients. We therefore evaluated whether it is possible to predict pulmonary complications after a lobectomy because even patients eligible for surgery develop pulmonary complications.

Many investigators have tried to identify the factors that predict the occurrence of postoperative complications following a lobectomy. Previous studies have shown a relationship between perioperative pulmonary complications and preoperative variables including age, ${ }^{8-10}$ sex ${ }^{8}$ obesity, ${ }^{11}$ chronic obstructive pulmonary disease, ${ }^{12}{ }^{13}$ cigarette smoking, ${ }^{10}$ the measurement of maximum oxygen consumption during exercise, ${ }^{14} \mathrm{FEV}_{1},{ }^{8} \% \mathrm{FEV}_{1},{ }^{10}$ predicted $\mathrm{FEV}_{1}{ }^{15}$ and transfer factor (TLCO). ${ }^{16}{ }^{17}$ However, these factors are not yet applicable at all institutions because the eligibility for surgery at each institution is different.

Our results suggest that the serum LDH level is strongly associated with postoperative morbidity. To our knowledge, only one report to date has previously evaluated the $\mathrm{LDH}$ level for predicting postoperative morbidity. ${ }^{18} \mathrm{~A}$ high $\mathrm{LDH}$ level indicates interstitial fibrosis of the lung following alveolar damage. No interstitial changes were detected on the CT scan and no liver dysfunction was seen in patients with a high LDH level in our series, although we did not investigate the isozyme of LDH. A high $\mathrm{LDH}$ level may indicate minimal interstitial damage of the lung which is not seen radiographically. We suggest that measurement of the $\mathrm{LDH}$ level, which is widely available, inexpensive, and quick and easy to perform, may have the potential to predict the occurrence of pulmonary complications.

In general, respiratory muscle weakness and semi-starvation is observed in patients following surgery. The contributing factors in these patients are postulated to be malnutrition related to biochemical, physiological, and ana- tomical changes, reduced blood flow to the respiratory muscles, and increased RV. An increase in RV means that the lung is still hyperinflated even after maximal expiratory effort, thereby increasing the lower secretion of sputum resulting from impaired movement of the diaphragm. An increased RV/TLC may thus also have an impact on the gas component in the alveolar space.

A low $\mathrm{PaO}_{2}$, which reflects diffusion impairment, unevenness of perfusion/ventilation, or existence of shunt, was independently associated with the occurrence of major postoperative pulmonary complications. Careful management may therefore be required for patients who simultaneously have a high level of $\mathrm{LDH}$, a raised RV/TLC, and a low $\mathrm{PaO}_{2}$ because these three factors seem to be correlated. In these patients preoperative pulmonary rehabilitation should be performed to prevent pulmonary complications, including the immediate cessation of smoking, use of bronchodilators and/or antibiotics, hydration, and chest physiotherapy.

In conclusion, LDH levels of $\geqslant 230 \mathrm{U} / 1$, RV/TLC of $\geqslant 30 \%$, and $\mathrm{PaO}_{2}$ of $<10.6 \mathrm{kPa}$ $(80 \mathrm{~mm} \mathrm{Hg})$ are the most predictive criteria for postoperative morbidity in surgical candidates who had both a predicted postoperative FVC of $>800 \mathrm{ml} / \mathrm{m}^{2}$ and $\mathrm{FEV}_{1}$ of $>600 \mathrm{ml} / \mathrm{m}^{2}$. An accurate prediction of postoperative morbidity would improve patient selection for operative procedures and also help to reduce the overall medical costs related to the treatment of such patients. Further studies in a prospective setting with a larger series of patients are required.

1 Landis SH, Murry T, Bolden S, et al. Cancer statistics, 1998. CA Cancer F Clin 1998;48:6-29.

2 Damstrup L, Poulson HS. Review of the curative role of radiotherapy in the treatment of non-small cell lung cancer. Lung Cancer 1994;11:153-78.

3 Grili R, Oxman AD, Julian JA. Chemotherapy for advanced non-small cell lung cancer; how much benefit with enough? f Clin Oncol 1993;11:1855-72.

4 American Thoracic Society. Standardization or spirometry: 1987 update. Am Rev Respi Dis 1987;136:1285-98.

5 SAS Institute Inc. SAS/STAT User's Guide, Release 6.03. Carey, NC: SAS Institute, 1988.

6 Mountain CF. Revisions in the international system for Mountain CF. Revisions in the internation
staging lung cancer. Chest 1997;111:1710-7.

7 Ginsberg RJ, Hill LD, Eagan RT, et al. Modern thirty-day Ginsberg RJ, Hill LD, Eagan RT, et al. Modern thirty-day
operative mortality for surgical resections for lung cancer. $\mathcal{F}$ Thorac Cardiovasc Surg 1983;86:654-8.

8 Keagy BA, LoresME, Starek PJK, et al. Elective pulmonary lobectomy: factors associated with mortality and operative morbidity. Ann Thorac Surg 1985;40:349-52.

9 Nagasaki F, Flehinger BJ, Martini N. Comparisons of surgery treatment of lung cancer. Chest 1982;82:25-9.

10 Dales RE, Dionne G, Leech JA, et al. Preoperative prediction of pulmonary complications following thoracic surgery. Chest 1993;104:155-9.

11 Tris GM. Preoperative evaluation of pulmonary function. Validity, indications, and benefits. Am Rev Respir Dis 1979; 119:293-310

12 Tarah S, Moffitt EA, Sessler AD, et al. Risk of anesthesia and surgery in patient with chronic bronchiolitis and chronic obstructive pulmonary disease. Surgery 1973;74:720-66.

13 Williams CD, Brenowitz JB. "Prohibitive" lung function and major surgical procedures. Am F Surg 1976;132:763-6.

14 Smith TP, Kinasewitz GT, Tucker WY, et al. Exercise capacity as a predictor of post-thoracotomy morbidity. $\mathrm{Am}$ Rev Respir Dis 1984;129:730-4.

15 Kearney DJ, Lee TH, Reilly JJ, et al. Assessment of operative risk in patients undergoing lung resection. Chest 1994;105: 753-9.

16 Markos J, Mullan BP, Hillman DR, et al. Preoperative assessment as a predictor of mortality and morbidity after lung resection. Am Rev Respir Dis 1989;139:902-10.

17 Fergusom MK, Little L, Rizzo L, et al. Diffusing capacity predicts morbidity and mortality after pulmonary resection. F Thorac Cardiovasc Surg 1988;96:894-900.

18 Mitsudomi T, Mizoue T, Yoshimatsu T, et al. Postoperative complications after pneumonectomy for treatment of lung cancer: multivariate analysis. F Surg Oncol 1996;61:218-22. 